\title{
Letter to the Editor Re: Comino, I., et al. Nutrients 2013, 5, $4250-4268$
}

\author{
Kamil K. Hozyasz \\ Pediatric Department, Institute of Mother and Child, 17a Kasprzaka Str., Warsaw, Poland; \\ E-Mail: khozyasz@verco.com.pl
}

Received: 19 November 2013; in revised form: 27 November 2013 / Accepted: 28 November 2013 /

Published: 5 December 2013

\section{Dear Editor,}

I read with interest the recently published review article titled "The gluten-free diet: testing alternative cereals tolerated by celiac patients" by Comino et al. [1] in Nutrients. However, there is very sparse data on so-called minor cereals and no data on candidate wild graminoids, which have been gathered in the past.

Availability of palatable gluten-free grain foods is expected to grow in coming years and this will provide many opportunities for agriculture companies to market new cereals that are tasty and affordable [2]. Three major trends in the gluten-free cereal market have been observed in the past 20 years: 1. introduction of new cultivars of formerly known gluten-free species (e.g., naked Avena sativa); 2. introduction of species of minor cereals from Africa and Asia (e.g., teff, proso millet, white fonio (Digitaria exilis), black fonio (Digitaria iburua), finger millet, jungle rice, Kodo millet, adlay, cattail millet); 3. introduction of species which, as wild graminoids, were previously gathered (e.g., Indian ricegrass, also known as montina-Achnatherum hymenoides) [3].

Indian ricegrass was a widely used food plant of Indian tribes in the USA and nowadays gluten-free all-purpose baking flour is marketed from this cultivated cereal. The Middle European traditions of culinary use of wild graminoids (manna grass - Glyceria fluitans, plicate sweet-grass - Glyceria nocata, cheat-Bromus secalinus, tribe Bromeae, and green bristle grass-Setaria glauca, tribe Paniceae) form an area for future research which may provide valuable gluten-free cereals. Glyceria is one of the main genera in the small, isolated tribe Meliceae [4]. In Middle Europe from medieval times until at least the 18th century, Glyceria seeds, the most expensive cereal, constituted an important part of taxes paid by peasants to landowners and was even exported [5,6]. Manna grass was used to make gruel (boiled with milk), desserts with butter and bread, which were highly valued. The importance of manna grass products as a Polish cuisine speciality was reported by foreigners visiting the country in the past [5]. Based on taxonomy, manna grass can be considered gluten-free; however, further studies 
are needed to measure its safety and usefulness for celiac patients. It needs to be stressed that it can take years to select cultivars of Glyceria fluitans suitable for intensive agriculture.

\section{References}

1. Comino, I.; de Lourdes Moreno, M.; Real, A.; Rodriguez-Herrera, A.; Barro, F.; Sousa, C. The gluten-free diet: Testing alternative cereals tolerated by celiac patients. Nutrients 2013, 5, 4250-4268.

2. Bogue, J.; Sorenson, D. The Marketing of Gluten-Free Cereal Products. In Gluten-Free Cereal Products and Beverages; Arendt, E.K., Dal Bello, F., Eds.; Elsevier: London, UK, 2008.

3. Hozyasz, K.K. Mało Znane Odmiany i Gatunki Zbóż Bezglutenowych (Minor Cultivars and Species of Gluten-Free Cereals). In Celiakia. Dieta Bezglutenowa-Poradnik; Stowarzyszenie Przyjaciół Chorych na Celiakię "Przekreślony Kłos": Bydgoszcz, Poland, 2012.

4. Tsvelev, N.N. Synopsis of the mannagrass genus, Glyceria (Poaceae). Bot. Zhurn. 2006, 91, $255-276$.

5. Luczaj, L.J.; Dumanowski, J.; Köhler, P.; Mueller-Bieniek, A. The use and economic value of manna grass (Glyceria) in Poland from the Middle Ages to the twentieth century. Hum. Ecol. 2012, 40, 721-733.

6. Luczaj, L.; Kőhler, P.; Piroznikow, E.; Graniszewska, M.; Pieroni, A.; Gervasi, T. Wild edible plants of Belarus: From Rostafinski's questionnaire of 1883 to the present. J. Ethnobiol. Ethnomed. 2013, 9, 21.

(C) 2013 by the authors; licensee MDPI, Basel, Switzerland. This article is an open access article distributed under the terms and conditions of the Creative Commons Attribution license (http://creativecommons.org/licenses/by/3.0/). 